\title{
Pathology of Students' Cell Phone Text Messages (Case study: Saghez's Payame Noor University)
}

\author{
Mahvash Janmardi \\ Department of Sociology \\ Payam Noor University \\ Islamic Republic of Iran \\ P. BOX: 1935_4697 \\ Tehran, Iran
}

\begin{abstract}
Modern communications technologies have opened widespread and diverse communication channels for people, and cell phones are among the phenomena, which in the late twentieth century and via transforming the human life, have had diverse individual and social impacts. Text message as one of the applications of cell phones as well as their growing trend among student users within an academic population requires to be explored. In this regard, the current research sought to analyze students' cell phone text messages. In order to arrange and configure the theoretical framework, theories of Satisfaction and Use by Engelhard, Habermas, Maccquail, Windall and Humens were used in a combined form. The research was conducted through a random sampling method and via a survey technique and by using a researcher made questionnaire among Payame Noor University students. The validity of the research's questionnaire was confirmed by the nominal and construct validity while its reliability was supported by Cronbach's alpha. The sampling method was simple random and the sample volume was 269 people. Data gathered were provided in two descriptive and inferential parts. Descriptive data indicated that in the sample population, the single, unemployed and Humanities group accounted for the highest percentage. Text messages, taking photos, Bluetooth, and filming were among the applications that cell phones would offer to students. The highest percentage of the sample population were found to send 150 messages and receive 41-60 messages per week. Non-academic friends were among the major receptors of messages. According to inferential results of the research, hypotheses pertaining to age, marriage status, job, motivation and reciprocal reaction, identity and satisfaction as well as sending messages were confirmed while other hypotheses were rejected.
\end{abstract}

Keywords: Text message, Students, University, Saghez

\section{Introduction}

Cell phone is among new technologies and emerging phenomena of the electronic era and digital age which assumes a special status within social layers of the society. Cell phone, like other technologies, may involve long term negative social outcomes, in addition to positive aspects. An increase in development of cell phones as a communication tool and a rise in the number of users in the current world have revealed a multitude of untold stories, such that users, without any limitations, express their own ideas through text messages and reveal feelings and emotions by creating a virtual world and a world of discourse with others. Growing trend of users is in such a way that text messages have laid new grounds for them while making them dependent. No such other means as cell phones have ever managed to result in such changes in the peoples' lifestyle and no such things have ever penetrated in the society. The users, by utilizing this communication system, disseminate and promote special habits and epitomes while exchanging and transferring thoughts with others. Cyber researches and distorted moral and legal values as a result of using cell phones are among the problems arising from this kind of technology, such that an increase in daily sending of text messages and immoral Bluetooth and distribution of scenes from the peoples' privacy have become a crisis in the way of moral security, thus causing challenges in the societal structures and privacy of the families. Modern technologies, via preparing and distributing easy access to scenes from the privacy and exposing various groups to public vision have engendered in the adoption of some measures as well as judicial prosecutions.

Easy and low costs access, low age and increased trend of users all indicate an active and increasing role of cell phones in the lives of peoples in the society. Universities as centers for growth and learning of ills resulting from cell phones have not remained immune from the risks stemming from cell phones and this communication tool has become a new crisis for educational officials as it speedily acquires momentum in educational centers such as schools and other higher education intuitions. Currently, exchange of text messages and Bluetooth apps have replaced many of the daily talks and whispering of students in the classroom. Fostering sending inappropriate text messages within the country's scientific construct, particularly among academic actors in the long run will entail 
adverse outcomes in the society. Inappropriate use of cell phones, due to improper utilization by users of text messages, misuse of trust in the messages by the receiver, unity collapse, dissemination of alienation among social groups, thinking havoc in people and divesting of thinking among age groups in many of the cases have all provided the possible range of affection with ills and totally, they have become threats for the future of the country in terms of social, economic political and cultural and even thinking and exchange health.

Considering abnormal outcomes of applying cell phones and special significance of this communication means within the academic social construct among students, it is necessary to understand possible outcomes and challenges of cell phones at universities and other places as well; because understanding the quality of using cell phones by students and the ends they are seeking is effective in understanding crises of the societal young population, particularly young people in the academic society. This is because of the fact that these young people, as they are young, adventurist, identity seeking and acquiring new experiences and information, seek to acquire and obtain criteria so to compensate for some parts of their own crises. In the direction of increasing trend of sending text messages among students at the university, the current research aimed to address the objectives of students in uncontrolled sending of text messages by this communicative means via applying some scientific methods.

\section{Statement of the problem}

In the direction of increasing needs and complexities of the human society, communication means has found various roles and forms, such that "Society moves from simplicity to complexity, the issue of communication and exchange of information assumes importance and communication system becomes critical and hence the society will find various roles" (Mo'tamed Nejad, 2005). Communication systems as one of the major social pillars linked with other existing systems in the community assumes importance in addition to exchange reciprocal relations in accounting for various needs of the human society.

Cell phones as one of the manifestations of modern communication technology has some secret harms due to obtaining an authoritative position in social interactions among actors and obtaining the highest rate of acceptability in daily relations. Cell phones, due to the fact its content is private has become a symbol of independence and false identity arising from unleashed wave of transference of digital information as well as maladaptive content being contradictory with societal customs and morality. Cell phones, as a strong and unique archive, contain communication information and capabilities which provide easy access for the users to up-to-date information, and the ego self-pretention with the least costs. Risks arising from cell phones in different social, economic, cultural, political, behavioral, psychological, medical legal, criminal fields require a deep understanding of its adverse effects. From a pathological point of view, cell phones can be considered a great source of generating fear and crises which have penetrated in the life's relations apparently and secretly. Cell phones in new societies which are eliminating traditions and living through spiritual communities may inflict damages on the societal structure. The more cell phones are utilized, the more they result in stringer relations with people. "Awakening of the public is among the new phenomenon of the global community and originates from the age of communications. When thousands of people are far from each other but live with each other with some relative thinking similarities and by using some special communications means, this is itself a kind of social abnormality which is of high importance in terms of value and significance" (Sarookhani, 1992).Phone users are like other ordinary users and players and some of their conducts are in one with moral and social standards common in the society but some of theirfunctions are contrary to the place of theiractivities. However, they act similarly in some other instances (Abdullahi, 2002). By breaking age, gender, ethnic, tribal, social, cultural, economic, political boundaries and limitations and as a result of improper use, cell phones have led to serious social and cultural ills among various groups in the society, because the cell phone interactive setting, via creating safe and free virtual space for users plays roles like an active encouragement in forming the expression of intimate and emotional feelings in order to acquire attraction among various groups, thus adding to the gap between the user and other actors in the family, groups and peers. Thus, could also engender negative repercussions for the future of the society. Unintentional messages often manifest as anti-moral and stressful and tension making issue in the society ranging from the family to the school setting, universities and institutions and organizations. Given complex and widespread nature of harmful effects of cell phone text messages, it is necessary to pay attention to this issue. Improper use of cell phones in scientific institutions requires cultural, political and social grounds, because the relevant harmful effects will be revealed in the long run in the educational center. Increasing trend of utilization of cell phones in social communications suggests an inappropriate addiction within the academic society. Cell phones account for a higher percentage among other communication technologies in students and the number of users is on the rise; thus answering such questions as understanding student users, level of use the way messages are sent, objectives of the senders and factors effective in growing inclination to this means indicate the issue of this current research. The current research, by believing in this matter and via using scientific methods sought to explore this crisis at universities. 


\section{Literature review}

In relation to the role of cell phones and relevant factors, many researches have been conducted in different scientific areas. Research on cell phone at universities is scant and in academic researches, there is little room for such researches. In a research by Kosari, Javadi Yegane and Kheir Khah (2006) with the title of Use and Satisfaction, the need for searching information (traffic, incidents, eventualities, paper titers), information relating to prices and kinds of entertainment,

Social benefits (rumors, chat, enjoying speaking to others, spending time and feeling comfort), emotional satisfaction (facilitation of relations with others), mobility and accessibility (loss of belonging to place for being related with others, permanent access without concern of places, all time access and all place access, maintaining permanent relations and accessibility for the elder members and patient members of the family) are addressed which arise from the satisfaction of having cell phone. Cell phones, in addition to such applications as fostering interpersonal relations, as they are mobile in all times and all places, have such uses as guaranteeing security, fashion, identity, coordination and entertainment and the like. Saeedi's research (2006) indicates that one can infer from the term "Pretension consumption" of cell phones and fashion that the cause of using cell phones is that the users pretend to consume and through "pretension consumption" within the theory of Torstein's welfare class, the reason of such idea in using cell phones is gaining a social status. In a research by Ekrami (2007), while assessing over 6000 short messages voluntarily, it was determined that around $32.6 \%$ of the messages were in the category of emotional issues, $7 \%$ in the area of advice and recommendations, $12.21 \%$ in the area of celebrations and religious rituals, $5.60 \%$ about jokes, $4.42 \%$ about scientiifc information, $5.30 \%$ about literary discussions, $1.67 \%$ about Islamic narratives, $8.86 \%$ about national media, $0.7 \%$ about advertisement and. 3. 35\% about social and political issues. According to researches by Pur Tahmasebi (2008), cell phones in addition to having some positive media aspects, culminate in adverse social outcomes.

The likelihood of talks, access to a multimedia environment, convergence, reciprocal interaction, rapid and effective access with high quality, creation of a rich virtual environment, reduction of costs and urban traffic, elimination of parts of limitations arising from physical disability are among some benefits raised regarding cell phones. Reduction of social interactions, ignoring values, emergence of cybercrimes and wrongdoings, destructive application of Bluetooth, and porn messages are among destructive effects of such electronic devices. Abdulmaleki's research (2008) indicates that using cell phone will affect heavily the solidarity and strength of the family and personality of the young people, where in the current time these negative impacts are higher than positive ones. Cell phones, in addition to impacting social relations, affect personal dimensions, including mental and physical health. Research by Hedayati (2010) in the area of effects of cell phones on the family and the young people illustrated that existence of cell phones has become pervasive and has had effects on economic basket, consolidation and disruption of families and personality of the young people quite considerably, where in the current time the negative effects are higher than the positive ones. In accordance with the research by Zokaee (2010), the young peoples' use of cell phones indicates its role in freedom of action and more choices that are offered for the young people. This media, while creating a new subculture communication problem has become a kind of a tool that both facilitates and compensates for their communication needs in an actual area. The young can easily get out of direct monitoring and control of families due to such benefits as remaining anonymous in the virtual space and curiosity which is offered in the space. Results by Ahmadi, Mehdi Zade and Aghili (2010) indicated that multi-purpose use of the cell phones like listening to radios, music, watching TV, and entering into the virtual world of the Internet are among features which strengthens modern personal identity and gives meaning to man's needs and wants as being focal point. Research by Yasami Nejad and Gol Mohamadyan (2011) illustrated that harmful use of cell phones was positively related with neuroticism and negatively and significantly related with extroversion. Step by step multiple regression analysis indicated that variables of neuroticism and extroversion would overall explain $10 \%$ of the variance of harmful use of cell phones. Other findings imply that there is a significant difference between female and male students with regard to using cell phones. Students majoring in technical and humanities groups do not have differences; as well using cell phones by single female and male students was higher than using cell phones by male and female married students. Research by Panahi, Faraji and Aslani (2012) indicates that students make use of cell phone's accessories for filling their own leisure time and communicating with friends. As much as $53.6 \%$ use it for listening to music, $31.1 \%$ for sending and receiving messages, $25.2 \%$ for conversation and $10 \%$ Bluetooth. The content of most messages being received and sent is jokes and jokes. Most Bluetooth is done for sharing music and photos. Results of Pearson correlation coefficient indicted that there is a relationship between dependency on cell phones and increased unhealthy relations and educational drop out. In the research by Babran and Akhavan (2012), a higher percentage of the sample population maintained that cell phones would result in creation of sense of freedom, independence, and higher self-confidence. Tests reveal that there is a significant relationship between using cell phones and reduced establishment of familial relations and student's' educational drop out. 
Research results by Manteghi and Din Parvar (2012) suggest that technologies like cell phones and the Internet have become effective in the formation of the hidden and informal identity of the users of this technology. Besides, the level of the families' information of the responding students concern they use hidden aspects of cell phones and the Internetis meaningfully less than students' close friends. Comparison of the way female and male students use hidden aspects of cell phones imply that female students make use of the hidden identity more significantly than boys. Research by Dadagaran and Azad Andish (2012) on students indicated that most respondents use cell phones less than two hours and most of them have been two to four years that they have cell phones. Also, most of them have more than 1 line and members of the family are informed of all their number lines.

Most of them make use of their text messages and send and receive jokes and romantic words through their messages. Also, they share most of the video files with their friend through Bluetooth. According to research results, it was determined that most respondents believed that having a cell phone instead of peers and classmates was not the reason why they have chosen cell phones. Having a cell phone results in freedom of action and sense of more independence. Most of their phone relations occur through cell phones with friends, however, they do not prefer to talk of their problems and how to eliminate them with their families. Cell phones do not result in fatigue and loss of energy for them (due to long use). According to research findings by Rostami Nejad et al. (2014), all the applications of cell phones among high school students in the province of Northern Khorasan are at a high level. Positive moral function has the highest average rate, and dependence and addiction as well as negative moral function equally stand in the second standing. In terms of gender, difference of average of dependence and addiction to cell phone, social constraints, negative educational function and negative moral function of girls with a higher average is statistically significant. Results indicated that there is a significant difference between ranking of each of the functions, and the positive moral function has the highest rate. Research results by Ata Dokht, Hamidi Far and Mohamadi (2014) showed that the degree to which high school students use cell phones was high (88/7\%), and this level was $98 / 4 \%$ among boy students which is higher than girls with the rate of $81 / 7 \%$. There is a significant difference between motivation for educational progress and achievement among students using cell phones and those who do not use such devices.

Findings also revealed that harmful use of cell phone is negatively related with educational performance and motivation for progress andachievement. According to research results by Moeed Far and Ganji (2010), most respondents used cell phones less than three hours per week and on average, students used to send 121 messages and receive 129 messages. The content of messages sent includes daily requirements, textbook issues, sexual issues, congratulation for celebrations, political jokes, porn and etc. Analytical results indicate that while limited collective communications has no effect on the level and kind of cell phone use, the motivation of the users has a significant effect on the application of phones. Also, there is a significant reverse correlation between time spent for companionship with the family and the level of using cell phones. According to Soheil's researches (2010) most phone communications of the young people can be classified in terms of time, place and goal and according to the results, over $17 \%$ of the sample under study spend their rime on daily activities and phone accessories which is not much helpful for them. Also, as much as 30\% of the students have stated that unnecessary contacts and messages waste their times. As quoted by Shahbazi, negative aspects of cell phones (Moeed far, 2008; Economides, 2008) and emergence of serious social and cultural ills due to failure to use the cell phones properly (Kafaee, 2010) should not be ignored. For example, Torkmandi (2010 refers to a poll in England which shows that people have considered cell phones as the worst invention in all times after the invention of the guns (Shahbazi, Baghiani Moghadam, Mohamad Lu, Motlagh and Masoudi Boroujeni, 2013). Foreign researches in the area of cell phone messages in the academic society meet with records such as internal researches. O'kief and Solanefsky (1995), while measuring satisfaction in phone applications, have identified sociability, entertainment, acquisition and management of time as dimensions of cell phone applications. In researches by Ling and Witri (1999) cases which describe using phones for coordinating activities of a person have been obtained from group interviews with parents having two jobs. In a research (2000) Peter S. Alexanderfound out that cell phones act as a symbol of adolescents. Though cell phone is not the only device that has this feature, principally all technologies play such roles. They not only affect their growth trend; rather their identity and the way they see "themselves" will be affected. Cell phones, in addition to the above cases, help them to comprehend their own identities.

Given Associated Press' research findings which were published online and carried out on 1465 people of the working age, as many as $18 \%$ of the participants stated that they had been rebuked due to negligent behaviors and improper use of cell phones like "speaking loudly, conversation with mobiles in public spaces and the like". By studying the conduct of 106 people who had overused phones, David Sheffield found out that $16 \%$ of them were undergoing behavioral problems. These problems will result in stress following addiction to cell phones and their personal life will be affected. Leving and Wi (2000) also showed that satisfaction resulting from cell phone applications are to a great extent similar to findings which have been mentioned in the literature related with ordinary phones and wireless communications. They have also mentioned instant mobility and access as unique 
dimensions of cell phone applications. Rich Ling (2001) in his research and study on adolescents concluded that girls, compared to boys own cell phones, because women, sooner than men at the age of 18 reach the peak point of using cell phones. Men a little bit later and at the age of 23 reach the peak of using mobiles.

Researches indicate that the kind of understanding obtained and the kind of using cell phones depend on exchanges and variations. Austin (2001) in a research with the heading of effects of using cell phones on peoples' perception andassumptions found out that technology can cause disruption. In a study conducted by Rutgers, half ofstudents admitted that last week they had been contacted and sent messages while at the class and $26 \%$ of the same students had left for answering (Shapiro, 2003).

In another study (Gerard, 2005), the more $m=$ limitation there is limitation for using cell phones during lecturer, the more students will have inclination for ignoring this subject. Qualitativestudy by Palin, Salzmann and Young (2001) on sociability process of mobile in daily life showed that man is transferred a proper and definite use from a vague and widespread point. Using cell phones is a personal affair which is extremely affected by social factors and processes. This study indicates there is a changing trend in the institutionalization of cell phones within the sociability process in the personal life. Permanent access, harassment, troubles and unwanted programs are imposed on the individual. Research by Palin, Salzmann and Young (2001) regarding cell phones illustrated that social use has not been among primary reasons of using this technology. In fact, business has been the first reason to accept this means; however, it has become a major communication device for majority of users in the short term. Fortunani (2001) has also examined social implications of cell phones in Italy as by considering and focusing on aesthetics. He attributes success of cell phones on being "fashion". Mobiles has become a "necessary extra means" which empowers users, and it shows how much others pay attention to them and how much tey are willing towards them. Having a mobile and its application transfer information about a person and affects formation of personal relations and mobiles have played roles in peoples' decision making. As quoted by Garcia-Montez (2006) in studying short messaging and the study by Taylor and Harper (2003( it was shown that this kind of communications has beenan accepted way and prevailed and often times, sending or receiving messages in transferring meaning is used for encouragement, punishment, rejection and acceptance.

There is no doubt, that mobiles are becoming part of our life and emergence of technologies have entailed various social and economic changes and transformed the very foundation of life. According to researches by Ling and Witri (2000), Ling (2004), Campbell (2007) some technologies cause people to feel sense of security, i.e. feelingof freedom and immunity from damages and ills. Quantitative and qualitative data of this research indicate that cell phones create the same sense of security for people who have chronic illness. Research by Torlo (2003) with regards to B.A. students' messages suggested that only one third of their messages have practical and applied content and they include emotional application, survival of friendships, love and social fairs attachment and higher intimacy. It seems that textual messages provide opportunities for intimate personal relations. Katz (2006) in his research on academic students in the United States suggested that one of the major users' motives is "Cell phone as fashion" which depends on "cultural background". According to this research fashion-oriented people use mobiles more than others and most people make use of such devices for being fashions. A research which was carried out by Crystal in England in 2008 illustrated that $81 \%$ of phone users were aged 15-24 years old in England and used short messages for expanding their social realitons. $37 \%$ of these messages were hateful of expression of love or hatred, though other applications such as threats, dissemination of rumors and doubtful contact of smugglers are also seen. Mackinaw (2008) found out that regular use of emails and cell phone messages and participation in the group of users will improve their life, specifically those having problems $\mathrm{n}$ the area of face to face talks. People who are mentally turbulent or isolated use such devices more.

\section{Theoretical framework}

Jean Kazeno maintains this thinking that mass communication media have super power isdisseminated among people who believe that this device could transform thoughts and guide all behaviors and powers (Kazeno, 1976). Mass communication media in a society are tools for communicating messages and expressing thoughts and transferring concepts to others. Investigating effects and impacts of this means is one of the most complex discussions in social deviance (Setoode, 1996). Chakotin maintained that with mass communication media, one can make masses conditional, create new habits and guide them in any direction (Sarokhani, 1996). De' flor and Ball Rokitch, in their own patterns regarding dependence on media stated that the major condition for the emergence of effects is the level of dependence of some of communication media, a channel for obtaining major information. In this regard, the current research seeks to analyze students' cell phone text messages. In order to arrange and configure the theoretical framework, theories of Satisfaction and Use by Engelhard, Habermas, Maccquail, Windall and Humens were used in a combined form. Lazarsfeld and Morton believed that many people have been affected by mass media and their potential power as they fear it. They argue that new mass communication media are strong tools that could be used for good and evil ends and if there is no favorable control, it is likely to use such devices more. Bryan Loader and Late Campbell (2001) argued that new technologies and rapid movements of capital result 
in insecurity and social and cultural inequality in the world. According to the Theory of Media Richness, the ability of the media influencing social relations has been exposed to their capacity in transferring messages and social symbols and media richness is considered to be determining factor in decision making the on the part of actors (Zokaee, 2009). Humens argues that in choosing between several actors, the result of an action is more valuable for a person, there is a higher possibility that the same person does that get engaged too; also if obedience of a value does not result in acquisition of satisfaction, its significance will decline and the other value will decline in terms of value and is followed by more value (Riders, 2000). Rogers (1995) argues that interactive innovations which are related with reciprocal communications could go through quicker adoption trend due to ability to rapidly absorb the user.

Tom Masich states that indifference to adverse behavior of users in using mobile means has caused others to have ordinary treatment with such behaviors. By expressing vacillation of communication content, Windall argues that long term effects will be focused attention more than short term effects. If a message is used for a long time, its effect will become more. Clapper, in addition to repetition of a message, considers the duration of a message so that the program can have the highest effect possible (Windall and Malakian, 1998). In the Engelhard's Scarcity Theory, it is said that personal priorities are reflections of this socioeconomic environment. According to the Engelhard's view, the individual attaches the highest values for those things whose supply is low (Englehart, 1999). Upon using this theory and also the theory of Maslow's hierarchy of needs in the application of modern information and virtual technologies, it can be stated that since in the community, the supply of some needs is low, thus, the users are seeking forthem in the virtual setting. In fact, according to this theory, it can be stated that the kind of using communication technologies by people is subjected to social and cultural limitations of their life environment (Shahbazi et al. 2012). Habermas also maintains that there are fundamental or authentic needs which are possessed by totally free people and these needs will be necessarily discovered by anyone who engages in a practical talk intimately (Steven, 2001). In the MC Quail's approach, beside variables of age, gender, education, income and job as factors constituting the application of mass media, there is an emphasis on the issue of time and place and degree of spending leisure time. For him, much use of media requires much time. Having said this, the reason why TV is seen much on the part of women is their much time (MC Quail, 2001). Using media has become diverse involving other social and demographic features, particularly age, income and gender and job.

In the Windhall's Communication Model, consumption of mass communication media and rewards resulting from this consumption are fundamental determined as peoples' basic needs. However, need has not been considered as the only factor for the consumption of mass media; rather it is considered one of the factors (Mohsenian Rad, 1989). For Windhall, consumption factors of mass communication media, in addition to consumption, include personal characteristics, personal expectation and perception of the communication means and the level of their access. Also, wind hall states in his own model that performing specialduty of any mass communication mean is linked with specialexpectations of that means and the reward the receptor obtains. Consumption of mass media and the resulting reward is fundamentally specified by peoples' basic needs. In the Wind hall'smodel the more content of communication means give more reward to the client or it is used in the direction of his need satisfaction, the level of using of that kind of content will be more (Ibid). Oneof the most notable theories is the study of factors affecting cell phones' application in the area of client's behavior is the theory of Katz' satisfaction and Use (Khaje Noori, 2010). The main assumption of the satisfaction and use theory is this that clients are more or less seeking some content actively which provide the highest satisfaction and the degree of satisfaction depends on needs a d interests of people (Mo'eed Far, 2008). In other words, people expose special behaviors for satisfaction andfilling their leisure time (Khaje Noori, 2010). The theory of use and satisfaction focuses on kind, content and the way clients use the media. It addresses this main question that "What do people do with mass media? This theory affirms that the activity of the client is the mediator of communication effects. Mobile has a close relationship with identity and many of the people owning cell phones have become dependenton it to some extent and consider it a necessary part of their loves. Mobile is part of me. No such thing has ever penetrated into our lives than mobile phones. Mobile phones are changing our lifestyles and they are opening places for themselves in our society. In fact, cell phone has become a part of the culture of modern societies. Cell phones are relied so heavily that losing a mobile phone is like physical collapse and disintegration, such that mobile removes a biologic need; mobile is becoming part of our body and it is therefore becoming us (Holm and Peters, 2001).

Holms believes in the emergence of the second era of media and in this era, interaction stands against combination and clients' powers rise. Cell phones undermine reciprocal interactions day by day, because people are interacting in the new public space, i.e. virtual space (Holms, 2005). Ameli states that cell phone is among the most individualistic tools of modern life which allows for identity self-assertion. When the individual gets out of the home, such flexible capabilities such as reciprocal or multi-reciprocal commucnition, communications being planned, choosing communications acceptance, choosing in accessing and not in accessing and multipurpose media use, listening to radio and music and viewing TV and entering into the internet virtual world are among the features 
which give meaning to the individual's wants and needs (Ameli, 2006). Giddens' theories (1991), while concerning personal identity reflective project, regarding the fact that how cell phone could result in creation of various identities, state that personal identity must be more or less created against backstage of varied life experiences and splitting inclinations (Holms and Peters,2001). Therefore, mobile communications allow for configuration and rationalization of interaction, particularly, regarding single participants (Leung, 1993). For Giddens, cell phones' users are intelligible people who have no concern or doubts and in reflecting identity, they are skillful (Holms and Peters, 2001). Postman also states that mobile in the current form might help some personal issues be resolved but it can undermine social and moral values and marginalizing them (Attaran, 2005). Landmark et al. (1998) found out that using new communication technologies reduce social relations in the ordinary forms result in reducesocial relations due to loneliness, depression and isolation.

Users' adverse use could be regarded as a social crisis and this issue creates problems and obstacles within the academic structure in regard to scientific development. Cell phones, by isolating users, create problems and even emergence of ills in the society. While cell phones reinforce virtual world and communications, they lead to reduced special relations. For Farjad, widespread advertisement will aggravate special problems for the young people and intensifies gap and distance between morality and moral customs. Young people's inclination will result in emergence of differences between them and their parents (Farjad, 1993).

Theoretical analysis model according to theorists' views

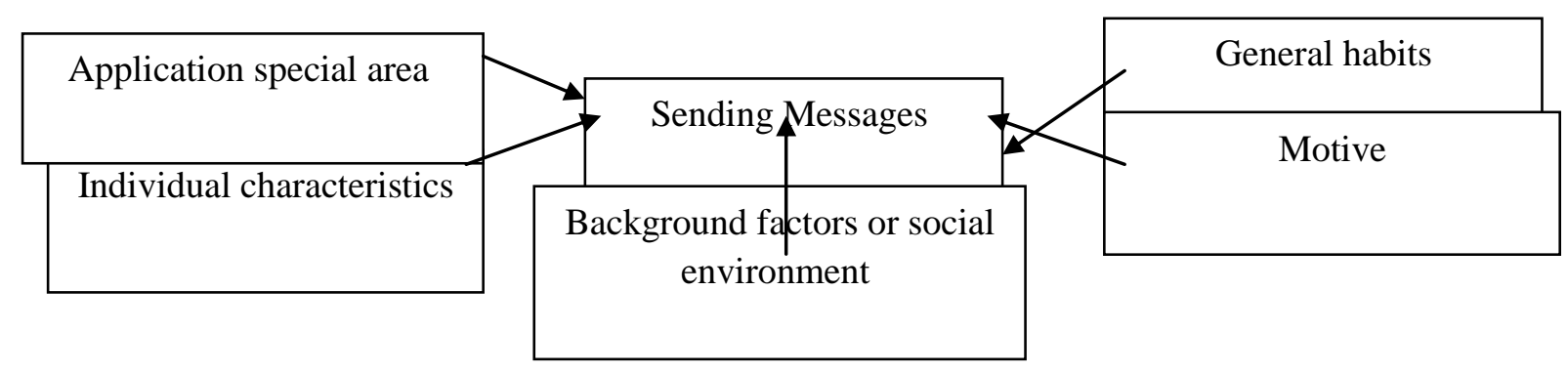

\section{Research hypotheses}

Independent variables of the research can be categorized in six classes: background variable or social environment (social, economic position, social communications limitations), variable of motive (satisfaction, motive, motivations of reciprocal creation and motives of identity), application of special area variable (place of use), variable of general habits of use (time, leisure time), and personal features (age, gender, educational group job and marriage status) which are measured by the dependent variable, i.e. sending messages.

\section{Methodology}

The methodology was a citation and survey and by using citation method, conceptual and theoretical dimensions were examined and then by applying survey method, the quality of distribution and relations between independent and dependent variables in the population under study was investigated. Data were analyzed by the SPSS software in terms of measurement level of each of the variable. To measure the reliability of the tool, Cronbach's alpha for each of the scale items were used and the alpha rate obtained was 0/85, confirming the reliability of the research tool. Statistical population of the research was comprised of all students studying in the Payame Noor University of Saghez, Kurdistan in the educational year of 2014-2015. As many as 269 people were selected by using the Cochran formula at the $5 \%$ standard error and at the confidence level of $95 \%$. Thus, the sample volume was determined based on gender to any of the scientific departments of humanities basics, agriculture and engineering fields.

\section{Research findings:}

Descriptive findings: Cell phones provide special virtual applications to users. In this area, some of the benefits of using cell phones and the reasons why they are pervasive can be reflected upon. Rapid access to overt and secret friends, the ability to hide information utilizing short messages services and easy access to ways of transferring audiovisual files are among the privileges which is favorable for any use; however, adverse use by users of cell phones in the scientific structure have caused behavioral and personality abnormalities.

Considering the fact that transference of information knows no limitation through cell phones and technical abilities in the phones like Bluetooth, multimedia files and the like penetrate any limitations. Under such conditions, student users are exposed to some information where they see their distinction power diverted. Cell phone capabilities are such immense that can be used mentally and physically by users. A failure of using cell phones is that one can be affected by creation of spacesfor talks in the scientific area. In addition to time consuming, one can refer to other 
issue such as lack of exchange if feelings and human emotions, limiting repertoire of and undermining verbal communications and the like.

\begin{tabular}{l|l|l}
\multicolumn{2}{l}{ Table, 1. Relative frequency distribution of characteristics of holders of cell phones } \\
\hline Marriage status & Frequency & Percent \\
\hline Single & 212 & $78.11 \%$ \\
Married & 57 & $21.19 \%$ \\
\hline Age & Frequency & Percent \\
\hline $21-23$ & 47 & $17.5 \%$ \\
$24-26$ & 53 & $19.8 \%$ \\
$27-29$ & 59 & $21.9 \%$ \\
$30-32$ & 43 & $15.9 \%$ \\
$33-35$ & 38 & $14.1 \%$ \\
Plus 35 & 29 & $10.8 \%$ \\
\hline Job & Frequency & Percent \\
\hline State job & 36 & $13.4 \%$ \\
Free job & 72 & $26.8 \%$ \\
Unemployed & 161 & $59.8 \%$ \\
\hline Gender & Frequency & Percent \\
\hline Woman & 139 & $51.7 \%$ \\
Man & 130 & $48.3 \%$ \\
\hline Educational group & Frequency & Percent \\
\hline Humanities & 129 & $47.9 \%$ \\
Basics sciences & 85 & $31.6 \%$ \\
Technical engineering & 31 & $11.6 \%$ \\
Agriculture & 24 & $8.9 \%$ \\
\hline Total & 269 & 100 \\
\hline
\end{tabular}

Source: Research findings

Research findings of 269 people indicates that $78.11 \%$ of the cell phone users were single, $59.8 \%$ were unemployed, $51.7 \%$ were women, $47.9 \%$ were included in humanities group and two age groups of $27-29$ and $24-$ 26 accounted for $21.9 \%$ and $19.8 \%$ of the respondents, because messages won't cause irritation of others for some reasons.

Table 2. Frequency distribution of the way student used cell phones' facilities at the university

\begin{tabular}{l|l|l}
\hline Variable (facilities) & Frequency & Percent \\
\hline Conversation & 17 & $6.32 \%$ \\
Message & 102 & $37.92 \%$ \\
Bluetooth & 33 & $12.27 \%$ \\
Taking photos & 42 & $15.61 \%$ \\
Filming & 29 & $10.78 \%$ \\
Entering into internet & 10 & $3.71 \%$ \\
Visual clips & 21 & $7.81 \%$ \\
Audio clips & 6 & $2.23 \%$ \\
Play and entertainment & 9 & $3.35 \%$ \\
\hline Total & 269 & 100 \\
\hline
\end{tabular}

Source: Research findings

In line with research results, students use cell phone applications including, 2.23\% listening to audio clips, 3.35\% paly and entertainment, $3.71 \%$ for using the Internet, $6.32 \%$ conversation, and $7.81 \%$ video clips. In prioritizing the utility of cell phone apps, messages accounted for $37.92 \%$, taking photo, $15.61 \%$, Bluetooth, $12.27 \%$ and filming, $10.78 \%$. 
Table 3: frequency distribution of messages sent and received by students in one week at the university

\begin{tabular}{l|l|l}
\hline Number of messages sent & Absolute frequency & Percentile frequency \\
\hline Less than 70 & 23 & $8.55 \%$ \\
$71-90$ & 29 & $10.78 \%$ \\
$91-110$ & 34 & $12.64 \%$ \\
$111-130$ & 48 & $17.84 \%$ \\
$131-150$ & 52 & $19.33 \%$ \\
Plus 150 & 83 & $30.86 \%$ \\
Total & 269 & 100 \\
\hline Number of messages received & Absolute frequency & Percentile frequency \\
\hline Less than 20 & 50 & $18.59 \%$ \\
$21-40$ & 23 & $8.55 \%$ \\
$41-60$ & 87 & $32.34 \%$ \\
$61-80$ & 69 & $25.65 \%$ \\
Plus 81 & 40 & $14.87 \%$ \\
Total & 269 & 100 \\
\hline
\end{tabular}

Source: Research findings

Table 3 data indicates that the highest percentage of the respondents, i.e. $30.86 \%$ used to send over 151 messages at the university, but the most people, i.e. 32.34\% received 41-60 messages per week and this indicates students being active in sending messages not in receiving messages.

Table 4: Frequency distribution of receptors of messages sent by students at the university

\begin{tabular}{l|l|l}
\hline Message receptors & Frequency & Percentage \\
\hline Parents & 17 & $6.32 \%$ \\
Sisters and brothers & 30 & $11.15 \%$ \\
Relatives & 12 & $4.46 \%$ \\
Academic friends & 131 & $48.7 \%$ \\
Non-academic friends & 43 & $15.99 \%$ \\
Academic personnel & 36 & $13.38 \%$ \\
Total & 269 & 100 \\
\hline
\end{tabular}

Source: Research findings

Given data of table 4 , the highest percentage if respondents, i.e. $48.7 \%$ of them used to send messages to academic friend and the least percentages used to send them to relatives, $4.46 \%$, parents, $6.32 \%$ and sisters and brothers, $11.16 \%$.

Table 5: Relative frequency distribution of reasons why cell phone users apply messaging at the university

\begin{tabular}{l|l|l}
\hline Variable & Frequency & Percentage \\
\hline $\begin{array}{l}\text { Security of expressing views in } \\
\text { social networks }\end{array}$ & 56 & $20.82 \%$ \\
\hline Self-assertion maj and new & 17 & $12.27 \%$ \\
\hline $\begin{array}{l}\text { Access to major } \\
\text { information }\end{array}$ & $6.32 \%$ \\
\hline $\begin{array}{l}\text { Feeling of superiority compared } \\
\text { to others }\end{array}$ & 29 & $10.78 \%$ \\
\hline $\begin{array}{l}\text { Facilitation and fostering } \\
\text { relations with others }\end{array}$ & 24 & $8.92 \%$ \\
\hline Fashions & 21 & $7.81 \%$ \\
\hline Coordinating activities & 15 & $5.58 \%$ \\
\hline $\begin{array}{l}\text { Freedom in expressing interest in } \\
\text { the opposite sex }\end{array}$ & 34 & $12.64 \%$ \\
\hline Spending leisure time & 30 & $11.15 \%$ \\
\hline Entertainment and recreation & 10 & $3.71 \%$ \\
\hline Total & 269 & 100 \\
\hline
\end{tabular}

Source: Research findings

According to data in table 5, a high percentage of the sample population, i.e. $20.82 \%$ consider security of expression of views as a reason for sending messages. $12.64 \%$ regarded interest for the opposite sex, $11.15 \%$ leisure time, $10.78 \%$ for sense of superiority over others among reasons for sending messages at the university. 
Table 6: Frequency distribution of content of messages sent by the students at the university

\begin{tabular}{l|l|l|l|l|l}
\hline Content & Very low & Low & Medium & Much & Very much \\
\hline Scientific & 48.4 & 20.2 & 18.5 & 8.2 & 4.7 \\
\hline Sports & 9.3 & 10.2 & 30.4 & 25.3 & 24.8 \\
\hline Cultural & 2.5 & 6 & 12.5 & 23.2 & 55.8 \\
\hline Political & 6.5 & 31.2 & 46.5 & 12.8 & 3 \\
\hline Social & 4.3 & 8.5 & 8.4 & 24.3 & 54.5 \\
\hline Jokes and jokes & 1.7 & 4.9 & 12.5 & 15.3 & 65.6 \\
\hline Economic & 52.3 & 21.5 & 14.7 & 7.5 & 4.3 \\
\hline Source:
\end{tabular}

Source: Research findings

Table data indicates that in the messages sent, scientific content accounted for $48.4 \%$, economic $52.3 \%$, which was the least rate. However, social content $54.5 \%$, jokes, $65.6 \%$ and cultural $55.8 \%$ accounted for the highest rate and the political content accounted for $46.5 \%$ at the medium range.

Table 7: University people in student's' messages

\begin{tabular}{l|l|l|l|l|l}
\hline People & Very low & Low & Medium & Much & Very much \\
\hline $\begin{array}{l}\text { High ranking officials } \\
\text { of the university }\end{array}$ & 18.9 & 47.8 & 27.4 & 2.5 & 3.4 \\
\hline $\begin{array}{l}\text { Low ranking officials } \\
\text { of the university }\end{array}$ & 2.1 & 13 & 35.7 & 49 & 14.2 \\
\hline $\begin{array}{l}\text { Academic } \\
\text { administrative } \\
\text { personnel }\end{array}$ & 0.9 & 6.4 & 12.5 & 20.6 & 59.6 \\
\hline Academic friends & 2.2 & 3.4 & 14.2 & 12.3 & 68.1 \\
\hline Professors & 3.7 & 0.6 & 2.5 & 13.7 & 78.5 \\
\hline
\end{tabular}

Source: Research findings

According to findings of table 7, high ranking officials of the university were placed in the very low rate of students' messages with acquiring $47.8 \%$. Low ranking officials $(49 \%)$ were at a higher rate and administrative officials $(59.6 \%)$, professors $(78.5 \%)$ and academic friends $(68.1 \%)$ were at very much rate within students messages.

Table 8: Time of sending messages by students at the university

\begin{tabular}{l|l|l|l|l|l}
\hline Time & Very low & Low & Medium & Much & Very much \\
\hline During class & 3.1 & 1.4 & 28.4 & 25.9 & 38.5 \\
\hline Roundtables & 1.1 & 3.4 & 16.2 & 26.1 & 53.2 \\
\hline $\begin{array}{l}\text { Lecture at the } \\
\text { university }\end{array}$ & 5.5 & 6.5 & 11.3 & 31.3 & 54.4 \\
\hline Ceremonies & 2.6 & 3.5 & 7.2 & 18.5 & 68.2 \\
\hline Free time & 2.4 & 6.7 & 7.2 & 12.4 & 71.3 \\
\hline
\end{tabular}

Source: Research findings

Table 8 indicates the lack of effect of time on sending messages, because percentages relating to very much sending messages during the class, roundtables, lectures, and free time indicate disintegration of variable of time for sending messages.

Table 9: Place of sending messages by students of the university

\begin{tabular}{l|l|l|l|l|l}
\hline Place & Very low & Low & Medium & Much & Very much \\
\hline Classroom & 7.6 & 14.1 & 17.2 & 25.3 & 35.8 \\
\hline Library & 2.8 & 6.3 & 7.2 & 22.4 & 61.3 \\
\hline Lab & 38.1 & 15.9 & 14.4 & 21.5 & 10.1 \\
\hline University saloon & 2.4 & 5.2 & 7.1 & 20.1 & 65.2 \\
\hline $\begin{array}{l}\text { Self-service } \\
\text { saloon }\end{array}$ & 4.3 & 16.1 & 19.4 & 22.4 & 37.8 \\
\hline Campus & 3.2 & 2.1 & 16.3 & 24.2 & 54.2 \\
\hline Chapel & 0 & 0 & 0 & 0 & 0 \\
\hline
\end{tabular}

Source: Research findings

According to research data, since time did not have role in sending messages, hence following this, given findings od table 9, all places and spaces of the university for sending messages have not been immune and the lab due to risk arising from substances accounted for the least number of message sent and no message was sent in the chapel due to its sanctity. 


\section{Inferential findings}

Table 10: Pearson test in measuring impacts of personal characteristics on sending messages

\begin{tabular}{l|l|l|l}
\hline Independent variable & Dependent variable & $\begin{array}{l}\text { Pearson correlation } \\
\text { coefficient }\end{array}$ & Significance \\
\hline Age & Sending messages & 3.12 & 0.63 \\
\hline Gender & Sending messages & 0.001 & 0.75 \\
\hline Educational group & Sending messages & 0.05 & 0.53 \\
\hline Marriage status & Sending messages & 1.22 & 0.33 \\
\hline Job & Sending messages & 2.39 & 0.80 \\
\hline
\end{tabular}

Source: Research findings

According to the findings, as an independent variable age has a significant relationship with sending messages. Test results indicate that gender does not play any role in message sending and sending messages does not have a significant relation with gender. Lack of relationship between variable of educational group and message sending indicates the equal inclination of educational groups on sending messages and no group did have superiority over the other. Marriage status and job are two effective variables in sending messages, because the two variables did have a significant relationship with message sending.

Table 11: Pearson test in measuring impacts of background hypotheses on sending messages

\begin{tabular}{l|l|l|l}
\hline Independent variable & dependent variable & $\begin{array}{l}\text { Pearson correlation } \\
\text { coefficient }\end{array}$ & Significance \\
\hline Socioeconomic position & Sending messages & 0.04 & 0.43 \\
\hline $\begin{array}{l}\text { Social communication } \\
\text { constraints }\end{array}$ & Sending messages & 0.01 & 0.29 \\
\hline
\end{tabular}

Source: Research findings

Test results indicate that there is no significant correlation between mass communication constraints and sending messages by cell phones. Lack of social communications limitation, given findings of table 11 has no effects on sending messages. Socioeconomic position did not have a significant relationship with sending messages. Therefore, the assumption of impacts of socioeconomic position on sending messages is rejected and two background variables i.e. socioeconomic and social communication constraints are not found to be significantly related with sending messages.

Table 12: Pearson test in measuring the effects of hypothesis of motives on sending messages

\begin{tabular}{l|l|l|l}
\hline Independent variable & dependent variable & $\begin{array}{l}\text { Pearson correlation } \\
\text { coefficient }\end{array}$ & Significance \\
\hline Satisfaction motive & Sending messages & 1.35 & 0.59 \\
\hline $\begin{array}{l}\text { Reciprocal action } \\
\text { motive }\end{array}$ & Sending messages & 1.41 & 0.87 \\
\hline Identity motive & Sending messages & 2.05 & 0.68 \\
\hline
\end{tabular}

Source: Research findings

Test results indicate that there is a significant and direct correlation between variable of satisfaction motive and sending messages and satisfaction motive with correlation rate of 1.35 is effective on sending messages. There is a direct and significant correlation between variable of reciprocal action motive and sending messages. Also, there is a direct and significant relationship between variable of identity motive and sending messages (2.05). Thus, the more motifs of satisfaction, reciprocal action and identity motive, the more messages will be sent.

Table 13: Pearson test in measuring the impacts of hypothesis of general habits on sending messages

\begin{tabular}{l|l|l|l}
\hline Independent variable & dependent variable & $\begin{array}{l}\text { Pearson correlation } \\
\text { coefficient }\end{array}$ & Significance \\
\hline Spending leisure time & Sending message & 0.04 & 0.51 \\
\hline Time & Sending messages & 0.01 & 0.79 \\
\hline
\end{tabular}

Source: Research findings 
There is no significant relationship between spending leisure time as a variable in general habits and dependent variable, i.e. sending messages and correlation coefficient of 0.04 confirms the rejection of the hypothesis. In fact, spending leisure time by students has no effect on sending messages. Also, there is no significant relationship between time and sending messages because sending messages knows no time.

Table 14: Pearson test in measuring the impacts of place in sending messages

\begin{tabular}{l|l|l|l}
\hline Independent variable & dependent variable & $\begin{array}{l}\text { Pearson correlation } \\
\text { coefficient }\end{array}$ & Significance \\
\hline Place & Sending messages & 0.06 & 0.91 \\
\hline \multicolumn{2}{c}{ Source: Research findings }
\end{tabular}

Correlation coefficient of table 14 is indicative of the lack of effects of the variable of place on sending messages, because correlation coefficient between the two variables is 0.06 .

\section{Conclusion}

Cell phone as a communication tool via influencing thoughts and ideas have brought about false needs by users and has affected the young people and divested from them power, will and action. Cell phone, via providing the likelihood of influencing on duty performance or special conduct of people and via penetrating into the minds of people have directed thoughts in its own direction and it has transformed mass thinking as well as humanity. Descriptive findings reveal that $78.11 \%$ of the phone holders are single, $59 / 8 \%$ are unemployed, $51.7 \%$ are women, 47.9\% are placedin Humanitiesgroup and two age groups of 27-29 and 24-26 are at the top with $21.9 \%$ and $19.8 \%$. Sending messages (37.92\%) is among the priorities of utilizing cell phone facilities. Higher percentage of respondents in sending 151 messages compared to low percentage of receiving messages at the university indicates activity in sending messages and in prioritizing utilization of cell phone facilities, message assumes $3.92 \%$, taking photo, $15.65 \%$, Bluetooth, $12.27 \%$, filming $10.78 \%$. In sending messages, academic friends are at the top by acquiring the highest percentage, but the least rate pertains to relatives with $4.465 \%$, patents, $6.32 \%$ and sisters and brothers with $11.15 \%$. A high percentage of the sample population, i.e. $20.82 \%$ consider security of expression of views as a reason for sending messages. $12.64 \%$ regarded interest for the opposite sex, $11.15 \%$ leisure time, $10.78 \%$ for sense of superiority over others among causes for sending messages at the university. high ranking officials of the university were placed in the very low rate of students' messages with acquiring $47.8 \%$.

Low ranking officials (49\%) were at a higher rate and administrative officials $(59.6 \%)$, professors $(78 / 5 \%)$ and academic friends $(68.1 \%)$ were at very much rate within students' messages. since time did not have role in sending messages, hence following this, all places and spaces of the university for sending messages have not been immune and the lab due to risk arising from substances accounted for the least number of message sent and no message was sent in the chapel due to its sanctity.According to research analytical findings, proving the assumption of relationship if age with sending messages is an affirmation of Mac quail's theory (2000), Rich Leung research (2001). Lack of relationship of variable of gender in sending messages is contrary to researches by Leung (2001), Nicole and Fleming (2010), Yasami Nejad and Gol Mohamadyan (2011), Manteghi and Din Parvar (2012), Ata Dokht and Hamidi Far and Mohamadi (2014), Rostami Nejad and Others (2015). Non-existence of significant relationship between educational group and sending messages indicates equal inclination of the educational groups to sending messages and no group was superior over the other. Marriage status is the effective variable in sending messages and an affirmation on researchresults by Yasami Nejad and Golmohamadi (2011). Test b results indicate that there is no significantrelationship between mass communication constraints and sending messages and this finding is consistent with researches by Mo'eed far (2010), Austen (2001), Gerard (2005).

Hypothesis of socioeconomic position effect on sending messages was rejected based on the Pearson correlation and this is contradictory with research by Saeedi (2007). Affirming hypothesis of satisfaction motive and sending messages is another fi dig if the analytical researches. This finding is in line with researches by Mo'eed far (2010), Taylor and Harper (2003), Leung and Wi (2000), O'kief and Solanefsky (1995), and Humens' view. There is no significant relationship between spending leisure time and dependent variable, i.e. sending messages. This is contradictory with Macquarie's theory. Time is not a factor affecting sending messages and according to research results, there is no significant relation between time and sending messages. Descriptive and analytical data are indicative of formative dissemination of social relations and a kind of mental vacuum by student actors in using cell phones, i.e. sending messages. This is because, security in the virtual space compared to present talks has provided widespread refection of mental hidden facets and has penetrated into cultural, political, social, economic layers. Under such conditions, emphasis on return to moral values is part of the road not taken; hence it should be directed that way. In this course, there is a need for improving this crisis, because it can prevent social ills. If this is not done, objectives will be lost and values be threatened (Abdullahi, 2005). 


\section{References}

Austin, C. (2001). Impact of Cell Phone Disruptions on Perceptions and Impressions. Journal of Experimental Social Psychology, 13 (2), 141-154

Ameli. SR (2006) "new individualism and mobile phone technology individualism and identity", Global Media Journal, Volume I, Issue I

Abdullahi Mohammad, (2004), "Social problems and process of change in Iran," Iranian Sociological Association, Volume I, Tehran: Agah publishing: 29.

Ahmad, Soraya M. Zadeh, Mohammad, Gholamreza Rezaei, Vahid (2010). The impact of mobile phone use on modern personal identity formation in adolescents in Tehran. Research Quarterly Year 16, No. 4: 150-125

Billieux, J., Van der Linden, M. , D’Acremont, M. , Ceschi, G. , \& Zermatten, A. (2007). Does impulsivity relate to the perceived dependence on actual use of the mobile phone? Applied Cognitive Psychology, 21, 527

Campbell, S.W (2007), A cross-cultural comparison of perceptions and uses of mobile telephony, New Media \& Society.

Cooper, G. (2000), The Mutable Mobile: Social Theory in the Wireless World. Paper presented at the "Wireless World" Workshop. University of Surrey, April 7.

Cox, Eva / Leonard, Helen (1990), Weaving Community Links: The Cost Benefits of Telephones in Maintaining the Social Fabric through the Unpaid Work of Women, The Distaff Papers, Australia

De Goumay, C. (2002), “Pretense of Intimacy in France”, In Mobile Communication, Private Talk, Public Performance, J.E. Katz and M.A. Aakhus, Editors, Perpetual Contact, Cambridge University Press

Fortunate, L. (2001). The Mobile Phone: An Identity on the Move. University of Trieste, Pordenon, Italy, Springer Verlag, London. 5,85-98.

Fortunati, L (2002), Italy: Stereotypes True and False', in J.E. Katz and

Giddens, Anthony (2004), "Sociology", translation M. patience, Eighth Edition, Tehran: Reed Publishing.

Garcia-montez, J.M. (2006). Changing in the Self Resulting from the Use of Mobile Phones. Media Culture Society Journal, 28, 67-82

Green N., Harper R.H.R., Murtagh G., Cooper G., (2001), "Configuring the Mobile User: Sociological and Industry Views ", Personal and Ubiquitous Computing Springer 5: 146-156 (2)

Hulme, M. and Peters S. (2001), Me, my phone and I: the role of the mobile phone, at http://www.cs.colorado.edu/ palen/chi_workshop/papers/HulmePeters.pdf (accessed21 November 2004):

Heurtin, J. P. (2001), "Managing One's Availability to Telephone Communication Through Mobile Phones: A French Study of the Development Dynamics of Mobile Phone Use". Personal and Ubiquitous Computing, Vol 5, (2 ), 99-108

Katz, J.E. and M. Aakhus (eds) (2002), "Mobile Culture of Children and Teenagers in Finland", in J.E. Katz and M. Aakhus (eds Perpetual Contact: Mobile Communication, Private Talk, Public Performance, pp. $170-92$. Cambridge: Cambridge University Press.

Khajenuri N. (2010), "Contact, communication and the communication media. Collective study of the relationship between the Iranian cultural ties quality of their use of visual media, Global Media Journal, Spring 1 (9): $39-31$

Katz.E.JE.Katz and Sugiyama. S. (2006), Mobile phone as fashion statements: evidence from student surveys in the US and Japan, Sage publication, 2006, New Media and society 8(2). P2.

Lange, K. (1993), Some concerns about the future of mobile communications in residential markets. In: Telecommunication: Limits to deregulation. Kristofferson, M (ed.) Amsterdam, IOS Press. 197-210

Lazars feld(p.f ), Merton R.K (1998): Miscommunication, popular Taste and organized social Action, in Bryson .(ed)The communication of Ideas ,New York ,Harper

Leung, L, and Wei, R. (2000) "More than just Talk on the Move: Uses and Gratifications of the Cellular Phone", In Journalism and Mass Communication Quarterly, Vol.77, (2),

Leung, L. (2007), "Unwillingness-to-communicate and college

students' motives in SMS mobile messaging ", Telematics and Informatics, 24: 115-129.

Leung and Wei; L. Leung and R. Wei (2000), "More than just talk on the move: uses and gratifications of the cellular phone", Journalism and Mass Communication Quarterly 77 (2000) (2), pp. 308-320

Monsef. SM (2012), "The social and cultural effects of mobile phones on secondary school students (Arak city)", Volume III, Issue 10, -191.149

Mohammad Abdollahi, (2005), Proceedings of social issues in Iran, and the need goals: 12

Mohammad Attaran. (2006), "Globalization and information technology education and training", Tehran, Press Institute of Technology developed the smart schools: 22

Mooshekaf Mohammad Hussain, (1995), "social pathology and sociological deviations", Tehran: Badr: 111

Ronald, Ingle hart (1995), "Cultural development in advanced industrial society", translation Mary chord, Tehran:

Tadkht Akbar, Vida Hamidi down Eisa Mohammadi 3, (2014), "The use and type of mobile phone use among high school students and its relationship with academic performance and achievement motivation", Journal of School Psychology, Issue 2 (10), 136-122

Thompson, John Brookshire (2000). Media and modernity: social theory about the media. Ali Ghorbani, Kasmaee. Tehran: Iranian establishment. 
Trkmndy H. (2010) Prohibiting the use of mobile classrooms in schools and class teachers in dealing with Ayatollah problem contd..

Ling, R (1997), "One Can Talk about Common Manners!: The Use of Mobile Telephones in Inappropriate Situations." In: Haddon, L (ed): Themes in Mobile Telephony. Final Report of the COST 248 Home and Work Group, Telia, Farsta,

Ling, R (2000), The Impact of the Mobile Telephone on Four Established Social Institutions, Presented at the ISSEI2000 Conference of the International Society for the Study of European Ideas, Bergen Norway, 14 - 18 August.

Manteghi .Morteza, Dinparvar. E. (2012) "identity formation hidden in mobile phone and Internet users," Journal of Information and Communication Technologies in Education Winter 2012, p. 26-15 in the third second number

Moeedfar, Said. And treasure. Ahmad (2010), "An Analysis of mobile phone applications among male and female high school students in Tehran. Global Media Journal, No. 8, S103-79

McKenna, K. Y. A. \&Bargh, J. A. (2008). Plan 9 from cyberspace: The implications of the Internet for personality and social psychology. Personal and Social Psychology Review, 4, 57-75.

McKenna, K. Y. A., Green, A. S., \& Gleason, M. E. J. (2002). Relationship formation on the Internet: What's the big attraction? Journal of Social Issues, 58, 9-31.

Motamednejad, K. (2005). "Information Society fundamental ideas, critical approach and global perspectives. Tehran's Allameh Tabatabaei University. Communications Research Center.: 21

Mac Kvayl, Dennis (2000).Audience Translated by Mehdi Montazerghaem. Tehran: Center for Studies and Media Researchresponse selection in predicting adolescents' mobile phone aggression-A pilot study. Journal of School Violence.

Okeefe, G.J. and Sulanowski, B.K. (1995) "More than just talk: Uses, Gratifications, and the Telephone", In Journalism and Mass communication Quarterly, Vol72/4

Panahi .Yaghob, Aslani .taher, Faraji .robab, betvaz. H. (2012), "Mobile phone dependence and psychosocial traumas in students: effects of SMS and Bluetooth» First National Congress of cyberspace and social problems emerging

Palen et al1; L. Palen, M. Salzman and E. Youngs (2001) "Discovery and integration of mobile communications in everyday life", Personal and Ubiquitous Computing, No 2: 109-122.

Peters et al O. Peters ; S. Allouch (2005) " "Always connected: a longitudinal field study of mobile communication", Annual Meeting of the International Communication Association , May 26-30.

Rostami Nejad Mohammad Ali, Asadi unitary .mhmdrza, Izzie. Mary, spiritual. Z. (2012), "disaster management cell phones in school deferment on its negative and positive functions", Studies on the education management can expect seven years, consecutive No. 25),

Sarookhani .B. , (1995), "The Sociology of Communication", fourth edition, Tehran: Publication Information: 95

Setoode. Hidayatullah, (1994), "Introduction to social pathology", first edition, Tehran: Sound of Light.:78-91

Saeedi, AA (2005), "Effects of Constant Touch on Consumer Behavior: A case study of mobile users in Iran", Global Media Journal: Issue On

Sohail.k(2010). Mobile phone :Calling and Texting patterns of college Students in pakisan ,International Journal of business and Management,5(4),26-30

Shahbazi, H., Baghiyani Moghadam. Mohseni, Alireza, M Broojeni.Dariush (2012), assessing the impact of mobile phones on social \& educational performance of students shahryzad2012, Global Media Journal, Volume 8, Number 2, successive Number 16, pp. 89-69

Shapira, N. A., \&Lessig, M. G., Goldsmith, T. D., \& et al. (2003). Problematic Internet use: Proposed classification and diagnostic criteria. Depression and Anxiety, 17 (4), 207-16.

Takebayashi, T., Varsier, N., Kikuchi, Y., \& et al. (2008). Mobile phone use, exposure to radiofrequency electromagnetic field, and brain tumour: A case-control study. British Journal of Cancer, 98 (3), 652-659.

Wu, C. I., Chan, C. W., Chen, Y. C. and Ishii, K. (2005), "Digital Opportunity: The Digital Gap between Openness and Closeness of Relational Divide Upon the Mobile Phone Usage", Int. J. Information Policy and Law, No. 2.

Windall, Sun et al. (1994), "Application of Theory of Communication." AR peasants. Tehran: Center for Studies and Media Research.

Yassami Nejad. Parisa, flowers Mhmdyan (2011) "The relationship between the five factors of traumatic strong character and use of mobile phones in Islamic Azad university students", Journal of Research in Social Psychology, Volume of: 105.79

Zokaei, Mohammed Saeed, Zadeh, V. (2010).Youth culture and mobile phones. Cultural Research Quarterly, Volume 2, Issue 7: 152-119 